\author{
사료 단백질의 Fraction과 In situ 단백질 분해율의 상관관계에 \\ 관한 연구 \\ 이세영* · 정유석* · 송재용* · 박성호* · 성하균* · 김현진* · 고종열** · 하종규* \\ 서울대학교 농생명공학부*, 농협중앙회 축산사료연구소**
}

\title{
Study on Correlation Between Feed Protein Fractions and In situ Protein Degradation Rate
}

\author{
S. Y. Lee*, Y. S. Chung*, J. Y. Song*, S. H. Park*, H. G. Sung*, H. J. Kim*, J. Y. Ko**
} and J. K. Ha*

School of Agricultural Biotechnology, Seoul National University * Livestock and Feed Research Institute, National Agricultural Cooperative Federation **

\begin{abstract}
This experiment was conducted to determine correlation between in vitro protein fractions and in situ protein degradation rate with major dairy protein sources (soybean meal, corn gluten meal, cotton seed meal, kapok seed meal and perilla meal). Five protein fractions were obtained according to the Cornell Net Carbohydate and Protein System(CNCPS), and in situ protein degradation rates were determined by technique using nylon bags incubated for $0,4,8,12$ and 24 hrs in the rumen of three Holstein steers. Fraction A was highest in kapok seed meal $(14.6 \%)$ and lowest in corn gluten meal $(0.6 \%)(\mathrm{P}<0.05)$. The highest B1, B2 and B3 fractions were contained in soybean meal (8.27\%), cotton seed meal (74\%), and perilla meal (40\%), respectively. Corn gluten meal was very high in fraction C. In situ protein degradation rate of soybean meal was $98 \%$, highest among five protein sources, and corn gluten meal had the lowest rate at $28 \%$. Correlation analysis showed that easily soluble fractions of both methods, in situ protein degradation rate and digestible protein fractions, and in situ protein degradation rate minus "a" and fraction B2+B3 were highly correlated. These results indicate that in vitro protein fractionation can be used in the estimation of in situ protein degradation.
\end{abstract}

(Key words : Protein fractions, In situ protein degradation, Correlation)

\begin{abstract}
I. 서 론
사료의 영양학적 가치를 판단하기 위해서는 일반성분 분석이나 각종 아미노산 함량 혹은 광물질 및 비타민의 양 등을 구하여 그 가치를 추정할 수 있으나, 반추동물은 반추위에서 미 생물에 의해 사료가 분해되기 때문에 실제 소

장에서 흡수되는 영양소는 사료내 영양소와 많 은 차이가 있다. 따라서 반추동물의 경우 사료 의 성분분석 만으로는 사료의 영양학적 가치를 평가하기 어렵다. 그래서 반추동물용 단백질 사료의 가치를 평가하는데 화학성분 분석 이외 에 in vivo 방법이나 in vitro, in situ 방법 등이 이용되고 있다. In vivo 방법은 직접 동물에서
\end{abstract}

Corresponding author: Ha, Jong Kyu, School of Agricultural Biotechnology, Seoul National University, Seoul, 151-921, Korea

Tel : 02-880-4809, Fax : 02-875-8710, E-mail : jongha@snu.ac.kr 
사료의 단백질 소화를 측정하기 때문에 비교적 정확하다고 할 수 있지만, 시간과 비용 등이 많이 소요된다(Van Straalen과 Tamminga, 1990). 이에 반해 in situ 방법은 기질을 담은 나일론 백을 반추위에 일정시간 배양한 후, 나일론백 에서 빠져나간 기질의 양을 측정하는 방법이기 때문에 비교적 간편하고, 반추위에 캐뉼라가 장착된 실험동물만이 필요하기 때문에 적은 비 용으로 수행 가능하여 현재까지 널리 이용되고 있다(Varvikko와 Lindberg, 1985). In vitro 방법 은 동물 생체실험의 한계를 극복할 수 있고, 시간에 대한 제약과 비용이 적어 널리 쓰이고 있다. In vitro 상에서 단백질 분해를 측정하는 방법에는 반추위액에 일정시간 배양후 분해율 을 측정하는 법(Tilley와 Terry, 1963), 가스발생 량을 통해 평가하는 방법(Menke와 Steingass, 1988), 단백질 분해효소를 이용하는 방법(Licitra 등, 1998; Luchini 등, 1996) 그리고 미생물체 단백질 합성 억제제를 이용한 배양법(Broderick, 1987) 등이 있다. 최근 비교적 널리 이용되고 있는 in vitro 방법으로 미국 Cornell 대학에서 제시한 Cornell Net Carbohydrate and Protein System(CNCPS)이 있는데 이는 원료사료의 단 백질을 여러 가지 용액에서의 용해되는 정도를 측정하여 5 개의 fraction(A, B1, B2, B3 및 $\mathrm{C})$ 으 로 구분하고 있다(Sniffen 등, 1992; Licitra 등, 1996). Fraction A는 비단백태 질소화합물 $(\mathrm{NPN}), \mathrm{B} 1$ 은 용해성 진정단백질, B2는 중성세 제 용해성 단백질, B3는 중성세제 불용성-산성 세제 용해성 단백질, $\mathrm{C}$ 는 산성세제 불용성 단 백질이다. 이 방법은 반추위나 위액에 배양할 필요가 없기 때문에 매우 간단한 방법이라 할 수 있다. 만약 단백질의 fraction으로 in situ 단 백질의 분해율을 추정할 수 있다면 사료 단백 질 품질측정이 훨씬 간편해 질 것이다. 하지만 이 방법은 반추위내 소화가 고려되지 않았기 때문에 단백질 fraction 결과가 원료사료의 반추 위내 소화율을 얼마나 정확하게 추정할 수 있 는지는 알 수 없다.

따라서 본 연구는 국내에서 사용되고 있는 몇 가지 단백질 원료사료를 사용하여 단백질 fraction과 in situ 단백질 분해율을 구한 다음
이들 사이에서의 상관관계를 보고자 실시하였 다.

\section{․ 재료 및 방법}

\section{1. 시험 사료}

단백질의 fraction과 in situ 분해율을 보기 위 하여 현재 국내에서 축우 사료 제조를 위하여 주로 사용 중인 5종의 단백질 사료 원료 즉, 탈피대두박(dehulled soybean meal, 국산), 콘글 루텐(corn gluten meal, 국산), 면실박(cottonseed meal, 중국산), 카폭박(kapok seed meal, 인도네 시아산) 및 임자박(perilla meal, 국산)을 시료로 사용하였다.

\section{2. 단백질 fraction 측정}

Licitra 등(1996)의 방법에 따라 사료 단백질 의 NPN(non-protein nitrogen, 비단백태질소화합 물), SOLP(soluble protein, 용해 단백질), NDIP(neutral detergent insoluble protein, 중성세 제 불용해단백질) 그리고 $\mathrm{ADIP}$ (acid detergent insoluble protein, 산성세제 불용해단백질)를 분 석하였으며, 각각의 단백질 fraction은 이들 성 분으로부터 다음과 같이 계산하였다.
$\mathrm{A}$ fraction $=\mathrm{NPN}$,
$\mathrm{B} 1$ fraction $=$ SOLP-NPN,
$\mathrm{B} 2$ fraction $=100-\mathrm{A}-\mathrm{B} 1-\mathrm{B} 3-\mathrm{C}$,
$\mathrm{B} 3$ fraction = NDIP-ADIP,
$\mathrm{C}$ fraction $=\mathrm{ADIP}$

\section{3. 원료 사료 단백질의 in situ 분해율 측정}

\section{1) 공시축 및 사양관리}

반추위 누관이 설치된 평균 체중이 $325 \pm$ $25 \mathrm{~kg}$ 인 홀스타인종 거세 수소 3 두를 사용하였 다. 시험기간 중 사료는 체중의 $2 \%$ 에 해당하는 양을 일일 2회로 나누어 급여하였으며 티모시 건초와 배합사료를 1:1로 혼합하여 급여하였고 음수와 미네랄 블럭은 자유 섭취토록 하였다. 급여한 사료의 성분은 Table 1 과 같다. 
Table 1. Nutrient contents of experimental feeds fed to steers

\begin{tabular}{lcrrrrr}
\hline & Moisture & CP & EE & CF & ADF & NDF \\
\hline \hline Timothy hay & 12.22 & 8.38 & 2.15 & 25.13 & 32.53 & 56.27 \\
Concentrate & 12.10 & 15.58 & 3.00 & 7.19 & 13.67 & 26.06 \\
\hline
\end{tabular}

2) Nylon bag 시험방법

홀스타인 거세우 3 두에 총 5 개의 원료사료를 각각 2개의 nylon bag에 넣어 반추위에 배양하 였다(6반복). Wiley mill을 이용하여 $1 \mathrm{~mm}$ 로 분 쇄한 각각의 원료사료는 $2 \mathrm{~g}$ 씩 nylon $\operatorname{bag}(5 \times$ $10 \mathrm{~cm} ; 50 \mu \mathrm{m}$ pore size)에 담고 입구를 봉한 후 아침사료 급여 직전에 반추위 내에 넣고 4,8 , 12 , 24시간 동안 배양하였다. 배양이 끝난 nylon bag은 반추위 누관으로부터 꺼내어 얼음 물에 침지 시켰다가 흐르는 수도물로 맑은 물 이 나올 때까지 세척한 다음 $60^{\circ} \mathrm{C}$ dry oven에 서 48시간 동안 건조하였다. 그리고 0 시간대 nylon bag은 반추위내 배양 없이 동일한 방법 으로 침지 및 세척을 한 후 건조되었다. 모든 시료는 48시간 건조한 후 건물 및 단백질 함량 을 측정하였다 (AOAC, 1990).

\section{3) 건물과 단백질의 소실율 및 분해율의 계 산}

원료사료 및 in situ 실험에서 수거된 시료의 $\mathrm{DM}$ 소실율 및 단백질 소실율은 배양기간 동안 소실된 양을 배양전 시료의 양에 대한 백분율 로 계산하였다.

각 시료의 건물 및 단백질 소실율 데이터를 SAS의 nonlinear regression procedure를 통해 Ørskov와 McDonald(1979)의 모델 계수 및 분해 율을 계산하였으며, 그 식은 다음과 같다.

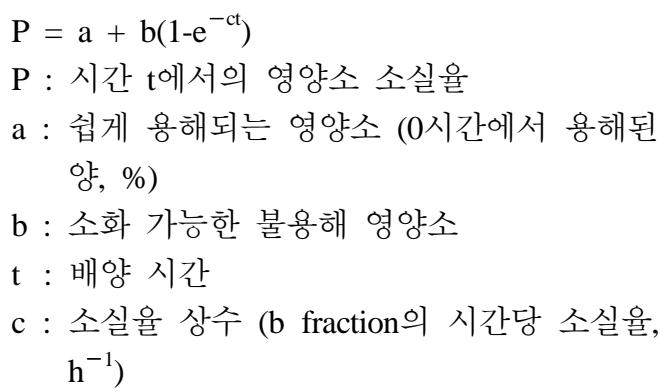

\section{4. 통계처리}

연구 결과에 대한 통계분석은 SAS(Statistical Analysis System, Version 9.1, USA, 2002) package program을 이용하였다. 소실율 계수는 nonlinear procedure를, 원료사료간 소실율 및 단 백질 fraction은 ANOVA procedure를, 그리고 측 정항목간 상관분석은 correlation procedure를 사 용하였다(Snedecor 등, 1989). 사료원료간 유의 적 차이는 $\mathrm{LSD}$ (least significant difference) 검정 을 통해 검정하였다.

\section{III. 결과 및 고찰}

\section{1. 사료원료의 단백질 fraction}

본 연구에 사용된 5종 사료원료들의 조성분 을 살펴보면 Table 2와 같다. 조단백질(CP) 함 량은 원료사료 중에서 콘글루텐이 $69.1 \%$ 로 가 장 높았고, 카폭박이 $32.8 \%$ 로 가장 낮았다. 조 지방(EE) 함량은 카폭박이, 조섬유 $(\mathrm{CF})$ 함량은 면실박이, 조회분(ash) 함량은 임자박이 다른 사료원료들보다 높았다.

이들 사료 원료들의 조성분 함량을 NRC (1996)와 비교했을 때 약간의 차이는 있었는데 이는 Van Straalen 등(1997)이 보고한 바와 같이 원산지, 성숙도, 품종, 가공 그리고 토양의 비 옥도 등에 의해 원료사료의 성분 함량에 차이 가 있었기 때문으로 보인다.

원료사료들의 단백질 fraction은 Table 3에서 보는 바와 같다. 비단백태질소화합물(NPN) 함 량은 원료사료 중에서 카폭박이 $14.6 \%$ 로 가장 높았고, 콘글루텐이 $0.6 \%$ 로 가장 낮았다 $(\mathrm{P}<$ 0.05). 용해 단백질(SP) 함량은 대두박과 카폭박 이 약 18 19\%로 가장 높았고 콘글루텐이 $4.8 \%$ 로 가장 낮았다 $(\mathrm{P}<0.05)$. 중성세제 불용해단백 
Table 2. Chemical composition of protein sources used for protein fractionation and in situ studies

\begin{tabular}{cccccc}
\hline \multirow{2}{*}{ Item } & \multicolumn{5}{c}{ Feedstuffs $^{10}$} \\
\cline { 2 - 6 } & SBM & CGM & CSM & KSM & PM \\
\hline \hline DM & 91.3 & 89.6 & 91.0 & 90.3 & 94.4 \\
CP & 45.1 & 69.1 & 47.6 & 32.8 & 42.0 \\
EE & 0.6 & 3.0 & 0.3 & 8.2 & 1.0 \\
CF & 5.8 & 1.0 & 17.5 & 17.3 & 15.5 \\
Ash & 7.4 & 3.3 & 5.9 & 7.0 & 8.6 \\
Ca & 0.5 & 0.2 & 0.3 & 0.7 & 1.5 \\
P & 0.6 & 0.3 & 0.8 & 0.7 & 1.3 \\
\hline
\end{tabular}

${ }^{1)}$ SBM, soybean meal; CGM, corn gluten meal; CSM, cotton seed meal; KSM, kapok seed meal; PM, perilla meal.

Table 3. Protein fractions of protein sources

\begin{tabular}{lcccccc}
\hline & SBM $^{1)}$ & CGM & CSM & KSM & PM & SEM $^{4)}$ \\
\hline \hline NPN $^{2)}$ & $10.2^{\mathrm{b}}$ & $0.6^{\mathrm{c}}$ & $10.2^{\mathrm{b}}$ & $14.6^{\mathrm{a}}$ & $10.7^{\mathrm{b}}$ & 1.27 \\
SOLP & $18.4^{\mathrm{a}}$ & $4.8^{\mathrm{d}}$ & $15.1^{\mathrm{b}}$ & $19.0^{\mathrm{a}}$ & $11.4^{\mathrm{c}}$ & 1.41 \\
NDIP & $7.4^{\mathrm{e}}$ & $43.9^{\mathrm{b}}$ & $11.3^{\mathrm{d}}$ & $20.3^{\mathrm{c}}$ & $56.9^{\mathrm{a}}$ & 5.15 \\
$\mathrm{ADIP}$ & $1.2^{\mathrm{d}}$ & $42.5^{\mathrm{a}}$ & $6.5^{\mathrm{c}}$ & $14.2^{\mathrm{b}}$ & $16.8^{\mathrm{b}}$ & 3.82 \\
\hline $\mathrm{A}^{3)}$ & $10.2^{\mathrm{b}}$ & $0.6^{\mathrm{c}}$ & $10.2^{\mathrm{b}}$ & $14.6^{\mathrm{a}}$ & $10.7^{\mathrm{b}}$ & 1.27 \\
$\mathrm{~B} 1$ & $8.3^{\mathrm{a}}$ & $4.2^{\mathrm{ab}}$ & $4.8^{\mathrm{a}}$ & $4.4^{\mathrm{ab}}$ & $0.8^{\mathrm{b}}$ & 0.72 \\
$\mathrm{~B} 2$ & $74.2^{\mathrm{a}}$ & $51.3^{\mathrm{c}}$ & $73.7^{\mathrm{a}}$ & $60.7^{\mathrm{b}}$ & $31.7^{\mathrm{d}}$ & 4.24 \\
$\mathrm{~B} 3$ & $6.2^{\mathrm{b}}$ & $1.5^{\mathrm{c}}$ & $4.7^{\mathrm{bc}}$ & $6.1^{\mathrm{b}}$ & $40.1^{\mathrm{a}}$ & 3.83 \\
$\mathrm{C}$ & $1.2^{\mathrm{d}}$ & $42.5^{\mathrm{a}}$ & $6.5^{\mathrm{c}}$ & $14.2^{\mathrm{b}}$ & $16.8^{\mathrm{b}}$ & 3.82 \\
\hline
\end{tabular}

${ }^{1)}$ SBM, soybean meal; CGM, corn gluten meal; CSM, cotton seed meal; KSM, kapok seed meal; PM, perilla meal.

2) NPN, non-protein nitrogen; SOLP, soluble protein; NDIP, neutral detergent insoluble protein; ADIP, acid detergent insoluble protein.

3) $\mathrm{A}=$ NPN; $\mathrm{B} 1=$ SOLP-NPN; B2 = 100-A-B1-B3-C; B3 = NDIP-ADIP; C = ADIP.

4) SEM, standard error of means.

a, b, c, d, e Means with different superscripts in the same row differ significantly $(\mathrm{P}<0.05)$.

질인 NDIP는 임자박이 약 $56.9 \%$ 로 가장 높았 고, 대두박이 약 $7.4 \%$ 로 가장 낮았다 $(\mathrm{P}<0.05)$. 산성세제 불용해단백질인 $\mathrm{ADIP}$ 는 콘글루텐이 약 $42.5 \%$ 로 가장 높았고, 대두박이 $1.2 \%$ 로 공 시한 원료 중 가장 낮았다 $(\mathrm{P}<0.05)$.

이들 분석값으로부터 단백질 fraction을 계산 하였는데, A fraction은 NPN 함량이고, B1 fraction은 NPN을 제외한 soluble protein을 말하
며, A와 B1 fraction은 반추위에서 빠르게 분해 되는 부분이다. B3 fraction은 중성세제에는 용 해되지 않지만, 산성세제에는 용해되는 부분으 로 NDIP에서 $\mathrm{ADIP}$ 를 빼서 계산하였으며, 반추 위에서 천천히 분해되어 상당부분은 반추위에 서 소화되지 않고 소장으로 넘어가며 소장에서 소화되는데 이 부분의 소화율은 평균 $80 \%$ 로 보고된 바 있다(CNCPS, 2003). C fraction은 
$\mathrm{ADIP}$ 로, 반추위 및 소장에서 분해 및 소화되지 않는 부분이다. $\mathrm{B} 2$ fraction은 전체 $\mathrm{CP}$ 중 나머 지 fraction값을 제외한 값으로 분해속도는 B1 과 B3 fraction의 사이로서, 사료의 특성과 섭취 수준 등에 따라 분해속도가 달라지며 반추위에 서 소화되지 않고 통과한 B2 fraction은 소장에 서 $100 \%$ 소화된다(CNCPS, 2003).

이러한 단백질 fraction의 분해 특성을 통해 살펴보았을 때 soluble fraction(A 및 B1 fraction) 의 함량이 높은 대두박과 카폭박은 반추위에서 초기 분해되는 양이 많을 것이고, B3 fraction의 함량이 높은 임자박은 반추위에서 천천히 분해 가 되며 소장으로 넘어가는 단백질의 양이 많 을 것으로 보인다. 그리고 콘글루텐은 반추위 및 소장에서 소화되지 않는 단백질의 양이 가 장 높다고 할 수 있다.

본 연구에서 얻은 단백질 fraction 결과를 CNCPS(2003) 데이터와 비교해 보면, 대두박과 면실박은 비슷하였으나 콘글루텐은 C fraction 값에서 많은 차이가 있었다. 카폭박과 임자박 의 단백질 fraction 데이터는 아직까지 보고되지 않아서 비교할 수가 없었다. 앞에서 원료사료 에 따른 조성분 함량의 차이에 대해서 언급한 것처럼, 단백질 fraction도 원료사료의 원산지, 성숙도, 품종, 가공 등에 의해 차이가 나타난
것으로 사료된다. 따라서 앞으로 지속적인 분 석과 연구를 통해 원료사료의 source별 분석이 되어야 원료사료의 fraction에 대한 정확한 평가 가 가능할 것이다.

\section{2. 단백질과 건물 소실율간의 상관 관계}

반추위에서 24시간 배양 후 원료사료들의 건 물 및 조단백질 분해상수와 분해율은 Table 4 에 제시되어 있다. 건물 분해율은 대두박이 $96.7 \%$ 로 원료사료 중에서 가장 높았고, 콘글루 텐과 임자박이 $45.1 \%$ 로 가장 낮았다 $(\mathrm{P}<0.05)$. 쉽게 용해되는 양을 나타내는 $\mathrm{a}$ 값도 대두박이 가장 높았고, 콘글루텐이 가장 낮았다 $(\mathrm{P}<0.05)$. 용해되지 않고 천천히 분해되는 양을 나타내는 $\mathrm{b}$ 값은 면실박과 대두박이 각각 $78.3 \%, 70.8 \%$ 로 가장 높았고, 카폭박이 $28.7 \%$ 로 가장 낮았다 $(\mathrm{P}<0.05)$. 불용성이며 천천히 분해되는 fraction $\mathrm{b}$ 의 분해속도를 나타내는 c값은 카폭박이 0.21 로 가장 높았고, 그 다음으로 대두박, 콘글루 텐, 임자박 그리고 면실박의 순으로 높았다 $(\mathrm{P}<0.05)$.

조단백질 분해율은 앞의 건물 분해율과 유사 한 경향을 보였다. 원료사료 중에서 대두박이 조단백질 분해율이 가장 높았고, 콘글루텐은

Table 4. In situ DM and CP degradation rate and parameters

\begin{tabular}{ccccccc}
\hline & SBM $^{1)}$ & CGM & CSM & KSM & PM & SEM $^{2)}$ \\
\hline \hline DM degradation (\%) & $96.7^{\mathrm{a}}$ & $45.1^{\mathrm{c}}$ & $55.6^{\mathrm{b}}$ & $53.1^{\mathrm{b}}$ & $44.6^{\mathrm{c}}$ & 3.61 \\
$\mathrm{a}^{3)}$ & $29.2^{\mathrm{a}}$ & $2.6^{\mathrm{d}}$ & $18.4^{\mathrm{c}}$ & $24.0^{\mathrm{b}}$ & $17.7^{\mathrm{c}}$ & 2.39 \\
$\mathrm{~b}$ & $70.8^{\mathrm{a}}$ & $52.3^{\mathrm{b}}$ & $78.3^{\mathrm{a}}$ & $28.7^{\mathrm{c}}$ & $36.4^{\mathrm{c}}$ & 5.21 \\
$\mathrm{c}$ & $0.10^{\mathrm{b}}$ & $0.07^{\mathrm{bc}}$ & $0.03^{\mathrm{d}}$ & $0.21^{\mathrm{a}}$ & $0.06^{\mathrm{cd}}$ & 0.02 \\
\hline CP degradation (\%) $^{\mathrm{c}}$ & $98.1^{\mathrm{a}}$ & $28.0^{\mathrm{e}}$ & $54.7^{\mathrm{c}}$ & $86.9^{\mathrm{b}}$ & $43.4^{\mathrm{d}}$ & 4.94 \\
$\mathrm{a}$ & $7.1^{\mathrm{b}}$ & $0.7^{\mathrm{c}}$ & $10.7^{\mathrm{b}}$ & $34.7^{\mathrm{a}}$ & $8.8^{\mathrm{b}}$ & 3.14 \\
$\mathrm{~b}$ & $92.9^{\mathrm{a}}$ & $85.1^{\mathrm{ab}}$ & $82.8^{\mathrm{ab}}$ & $50.4^{\mathrm{b}}$ & $60.3^{\mathrm{ab}}$ & 5.44 \\
$\mathrm{c}$ & $0.11^{\mathrm{b}}$ & $0.02^{\mathrm{b}}$ & $0.03^{\mathrm{b}}$ & $0.30^{\mathrm{a}}$ & $0.05^{\mathrm{b}}$ & 0.03 \\
\hline
\end{tabular}

\footnotetext{
${ }^{1)}$ SBM, soybean meal; CGM, corn gluten meal; CSM, cotton seed meal; KSM, kapok seed meal; PM, perilla meal.

2) SEM, standard error of means.

${ }^{3)}$ Values of $\mathrm{a}, \mathrm{b}$ and $\mathrm{c}$ were derived from the equation of $\mathrm{P}=\mathrm{a}+\mathrm{b}\left(1-\mathrm{e}^{-\mathrm{ct}}\right.$ ) (Ørskov and McDonald, 1979).

$\mathrm{P}$ is $\mathrm{DM}$ or CP degradation at time $\mathrm{t}(\mathrm{h})$, $\mathrm{a}$ is the soluble fraction, $\mathrm{b}$ is the potentially degradable fraction and $c$ is the rate of degradation $(/ h)$ of $b$ fraction.

a, b, c, d, e Means with different superscripts in the same row differ significantly $(\mathrm{P}<0.05)$.
} 
가장 낮았다 $(\mathrm{P}<0.05)$. 대두박의 경우 쉽게 용해 되는 부분 (a값)은 적지만, 용해되지 않고 소화 가능한 부분 (b값)이 많고 소화속도 (c값)가 빠 르기 때문에 결과적으로 분해율이 높았다. 하 지만, 콘글루텐의 경우 소화가능한 부분은 많 지만 쉽게 용해되는 부분이 적고 소화속도가 느려 결과적으로 단백질 분해율이 낮았다. 카 폭박은 대두박 다음으로 조단백질 분해율이 높 았는데, 카폭박의 경우 a와 c값은 높았으나, b 값은 낮았다. 즉, 카폭박은 반추위내에서 많은 양이 용해되며 (a값), 용해되지 않고 소화가능한 부분은 빠르게 분해되지만 (c값), 그 양 (b값)이 많지 않았다. 면실박과 임자박의 분해율은 카 폭박보다 낮고 콘글루텐보다 높았다 $(\mathrm{P}<0.05)$. 대두박과 비교했을 때 면실박과 임자박의 a값 은 대두박과 비슷하지만 $\mathrm{b}$ 와 $\mathrm{c}$ 값이 작았다. 즉, 소화가능한 부분이 적고 소화속도도 느려 단백 질 분해율이 낮았다.

윤 등(1990)은 단백질 원료사료를 면양의 반 추위에서 72 시간 배양한 후 단백질 소화속도를 측정하였는데, 대두박, 콘글루텐, 면실박 및 임 자박의 소화속도는 각각 $0.099,0.028,0.045$, 0.040 이라고 보고하였다. 이는 대두박이 높고 콘글루텐은 낮았으며 면실박과 임자박은 그 사 이인 본 연구결과와 일치하였다. Erasmus 등 (1994)은 반추위에서 16시간 배양후 면실박과 콘글루텐의 조단백질 분해율이 각각 42.5와 $18.6 \%$ 라고 보고하였으며 해바라기박과 땅콩박 은 반추위에서 단백질 분해율이 높고, 대두박 과 면실박은 중간이며, 그리고 어분, 콘글루텐 및 혈분은 낮다고 보고하였다. NRC(2001)에서 는 단백질 사료원료의 반추위내에서 소화되는 단백질(RDP) 양을 제시하였는데, 대두박, 콘글 루텐 및 면실박의 $\mathrm{RDP}$ 는 각각 $76 \%, 36 \%, 52 \%$ 였다. 본 연구에서 대두박의 분해율이 NRC (2001)에서 제시한 값보다 높았는데, 이는 대두 피를 제거한 탈피대두박을 사용하였기 때문일 것이다. Ceresnakova 등(2002)은 원료사료중 대 두박, 해바라기박, 채종박, 아마박은 반추위에 서 단백질 소실율이 높았고, 콘글루텐과 전지 대두는 낮은 것으로 보고하였다. Cozzi와 Polan(1994)도 콘글루텐의 CP 소실율이 다른 단
백질 원료사료에 비해 낮다고 보고하였는데, 이는 콘글루텐의 젤라틴 성질과 미생물의 부착 표면적의 감소 때문인 것으로 사료된다(Stern과 Satter, 1982).

\section{3. 사료 단백질의 fraction과 in situ 단백질 분해율간의 상관관계}

Table 5는 in situ 소실율과 단백질 fraction 간 의 상관관계를 나타낸 것이다. 건물 소실율과 조단백질 소실율 간의 상관계수는 0.84 로 상관 관계가 높았다 $(\mathrm{P}<0.01)$. 원료사료 중 쉽게 용해 되는 부분인 In situ의 a값과 단백질 fraction A 사이의 상관계수는 0.78 이었고, $\mathrm{a}$ 값과 $\mathrm{A}+\mathrm{B} 1$ fraction 간의 상관계수는 0.67 이었다 $(\mathrm{P}<0.01)$. 하 지만 용해되지 않고 천천히 분해되는 부분인 in situ의 b값과 단백질 fraction $\mathrm{B} 2+\mathrm{B} 3$ 사이에 서는 상관관계가 없었다 $(\mathrm{P}>0.05)$. In situ $\mathrm{a}+\mathrm{b}$ 값

Table 5. Correlation coefficient between in situ CP parameters and protein fractions

\begin{tabular}{|c|c|c|}
\hline & $\begin{array}{l}\text { Correlation } \\
\text { coefficient }\end{array}$ & Probability \\
\hline $\begin{array}{l}\text { DM degradation vs CP } \\
\text { degradation }\end{array}$ & 0.84 & $<0.01$ \\
\hline$a^{1)} \operatorname{vs~}^{2)}$ & 0.75 & $<0.01$ \\
\hline vs $A+B 1$ & 0.66 & $<0.01$ \\
\hline vs B2+B3 & 0.04 & 0.876 \\
\hline $\mathrm{a}+\mathrm{b}$ vs $\mathrm{A}+\mathrm{B} 1+\mathrm{B} 2+\mathrm{B} 3$ & 0.16 & 0.579 \\
\hline $\begin{array}{l}\text { CP degradation vs } \\
\mathrm{A}+\mathrm{B} 1+\mathrm{B} 2+\mathrm{B} 3\end{array}$ & 0.75 & $<0.01$ \\
\hline $\begin{array}{l}\text { CP degradation - a } \\
\text { vs B2+B3 }\end{array}$ & 0.65 & $<0.01$ \\
\hline \multicolumn{3}{|c|}{$\begin{array}{l}\text { 1) Values of a, b and c were derived from the } \\
\text { equation of } \mathrm{P}=\mathrm{a}+\mathrm{b}\left(1-\mathrm{e}^{-\mathrm{ct}}\right) \text { (Ørskov and } \\
\text { McDonald, 1979). P is DM or CP degradation at } \\
\text { time } \mathrm{t}(\mathrm{h}) \text {, a is the soluble fraction, b is the } \\
\text { potentially degradable fraction and } \mathrm{c} \text { is the rate of } \\
\text { degradation (/h) of b fraction. } \\
\text { 2) Protein fraction A, non-protein nitrogen; B1, buffer- } \\
\text { soluble protein; B2, buffer-insoluble but neutral } \\
\text { detergent soluble protein; B3, neutral detergent } \\
\text { insoluble but acid detergent soluble protein; C, acid } \\
\text { detergent insoluble protein. }\end{array}$} \\
\hline
\end{tabular}


과 단백질 fraction $\mathrm{A}+\mathrm{B} 1+\mathrm{B} 2+\mathrm{B} 3$ 사이에서도 상관관계는 없었지만, 조단백질 분해율과 단백 질 fraction $\mathrm{A}+\mathrm{B} 1+\mathrm{B} 2+\mathrm{B} 3$ 사이에서는 상관계 수가 0.75 로서 상관관계가 높았다 $(\mathrm{P}<0.01)$. 지금 까지 상관관계를 살펴본 결과, 실제 단백질 분 해율과 분해 가능한 단백질 fraction $(\mathrm{A}+\mathrm{B} 1+$ $\mathrm{B} 2+\mathrm{B} 3)$ 에서는 상관관계가 있었으나, in situ의 $\mathrm{b}$ 값과 단백질 fraction $\mathrm{B} 2+\mathrm{B} 3$ 사이에서는 상관 관계가 없었다. 이는 in situ의 b값이 실제 분해 율보다 높게 계산되었기 때문일 것이다. 실제 로 이 $\mathrm{b}$ 값은 소화가능한 양을 나타내는 것으로 서 소화속도에 따라 일정시간 후의 소화된 양 이 상당히 다를 수 있다. 콘글루텐과 면실박의 $\mathrm{b}$ 값은 $80 \%$ 이상이지만 실제 분해율은 $55 \%$ 이 하인 점이 이를 대변해준다. 그래서 $\mathrm{CP}$ 분해율 에서 $\mathrm{a}$ 값을 제외한 값(CP-a)과 $\mathrm{B} 2+\mathrm{B} 3$ fraction 간에는 상관관계가 0.65 로서 비교적 상관관계 가 높았다 $(\mathrm{P}<0.01)$. Zhao와 $\mathrm{CaO}(2004)$ 는 다중회 귀분석을 통해 CNCPS 단백질 fraction 과 in vitro CP 분해율간의 회귀식을 구하였으며, 단 백질 fraction으로 CP 분해율을 추정할 수 있다 고 제시하였다. 또한 Shannak 등(2000)도 단백 질 fraction으로부터 in situ UDP (undegradable protein)의 양을 정확하게 추정할 수 있다고 보고 하였다.

따라서 본 연구에서 얻은 원료사료의 단백질 fraction과 in situ 분해율과의 상관관계를 종합 해 보면, 두 방법에서 쉽게 용해되는 성분간이 나 in situ 조단백질 분해율과 소화가능한 단백 질 fraction간, 그리고 in situ 조단백질 분해율에 서 $\mathrm{a}$ 값을 제외한 값과 $\mathrm{B} 2+\mathrm{B} 3$ fraction 사이에 상관관계가 있었다. 이로 보아 화학적 방법을 기초로 한 fractionation 결과로부터 in situ 분해 율을 추정하는 것이 부분적이나마 가능한 것으 로 사료된다. 그러나 좀더 정확한 추정이 가능 하기 위해서는 더 많은 원료사료에 대한 분석 자료가 필요하다.

\section{IV. 요 약}

본 연구는 국내에서 사용되고 있는 몇 가지 단백질 원료사료를 사용하여 단백질 fraction과 in situ 단백질 분해율을 구한 다음 이들 사이 에서의 상관관계를 살펴보고자 실시하였다. 원 료사료는 대두박, 콘글루텐, 면실박, 카폭박 및 임자박이었다. 단백질 fraction은 CNCPS에서 제 시하는 방법으로 구하였으며, in situ 단백질 분 해율은 캐뉼라가 장착된 홀스타인 거세우 3 두 를 이용하여 반추위에서 원료사료를 $4,8,12$ 및 24시간 배양하여 구하였다.

단백질 fraction 중 $\mathrm{A}$ fraction은 카폭박이 $14.6 \%$ 로 가장 높았고, 콘글루텐이 $0.6 \%$ 로 가장 낮았다 $(\mathrm{P}<0.05)$. B1 fraction은 대두박이 $8.27 \%$ 로 가장 높았으며, B2 fraction은 대두박과 면실박 이 $74 \%$ 로 가장 높았다. B3 fraction은 임자박이 $40 \%$ 로 다른 원료사료에 비교해 뚜렷하게 높았 다. C fraction은 콘글루텐이 약 42.5\%로 가장 높았다. In situ 조단백질 분해율은 대두박이 $98 \%$ 로 가장 높았고, 콘글루텐은 $28 \%$ 로 가장 낮았다. 단백질 fraction과 in situ 분해율 사이의 상관관계를 보면, 쉽게 용해되는 부분 (A, B1 fraction vs a값) 사이에, in situ 조단백질 분해 율과 소화가능한 단백질 fraction 사이에, 그리 고 in situ 조단백질 분해율에서 a값을 제외한 값과 $\mathrm{B} 2+\mathrm{B} 3$ fraction 사이에는 상관관계가 높 았다 $(\mathrm{P}<0.01)$. 본 연구결과에 의하면, 단백질 fraction은 원료사료의 반추위내 분해율을 추정 하는 데 이용될 수 있을 것으로 사료되며, 앞 으로 더 정확한 평가를 위해서는 더 많은 원료 사료에 대한 분석이 필요하다고 본다.

$$
\mathrm{V} \text {. 사 사 }
$$

본 연구는 농촌진흥청 축산연구소의 일부 연 구비 지원 (20060095)에 의해 수행되었음을 밝 힙니다.

\section{VI. 인 용 문 헌}

1. 윤칠석, 김덕영, 이남형. 1990. In situ 방법에 의 한 국내이용 단백질 사료원에 대한 단백질 분해 율에 관한 조사. 한국축산학회지. 32(5):264-270.

2. AOAC. 1990. Official Methods of Analysis. 15th ed. Association of Official Analytical Chemists. Washington, D. C., USA. 
3. Broderick, G. A. 1987. Determination of protein degradation rates using a rumen in vitro system containing inhibitors of microbial nitrogen metabolism. Br. J. Nutr. 58:463-475.

4. Ceresnakova, Z., Sommer, A., Chirenkova, M. and Dolesova, P. 2002. Amino acid profile of escaped feed protein after rumen incubation and their intestinal digestibility. Arch. Anim. Nutr. 56:409-418.

5. CNCPS. 2003. Corrnell Net Carbohydrate and Protein System. A manual for the Net Carbohydrate and Protein System for Evaluation Herd Nutrition and Nutrient Excretion. CNCPS ver. 5.0. Cornell Univ., Ithaca, NY.

6. Cozzi, G. and Polan, C. E. 1994. Corn gluten meal or dried brewers grains as partial replacement for soybean meal in the diets of Holstein cows. J. Dairy Sci. 77:825-834.

7. Erasmus, L. J., Botha, P. M., Cruywagen, C. W. and Meissner, H. H. 1994. Amino acid profile and intestinal digestibility in dairy cows of rumenundegradable protein from various feedstuffs. J. Dairy Sci. 77:541-551.

8. Licitra, G., Hernandez, T. M. and Van Soest, P. J. 1996. Standardization of procedures for nitrogen fractionation of ruminant feeds. Anim. Feed Sci. Technol. 57:347-358.

9. Licitra, G., Lauria, F., Carpino, S., Schadt, I., Sniffen, C. J. and Van Soest, P. J. 1998. Improvement of the Streptomyces griseus method for degradable protein in ruminant feeds. Anim. Feed Sci. Technol. 72:1-10.

10. Luchini, N. D., Broderick, G. A. and Combs, D. K. 1996. Characterization of the proteolytic activity of commercial proteases and strained ruminal fluid. J. Anim. Sci. 74:685-692.

11. Menke, K. H. and Steingass, H. 1988. Estimation of the energetic feed value obtained from chemical analysis and in vitro gas production using rumen fluid. Anim. Res. Dev. 28:7-55.

12. NRC. 1996. Nutrient Requirements of Beef Cattle. 7th rev. ed. National Academy Press. Washington, D.C.

13. NRC. 2001. Nutrient Requirements of Dairy Cattle. 7th rev. ed. National Academy Press. Washington, D.C.

14. Ørskov, E. R. and McDonald, P. 1979. The estimation of protein degradability in the rumen from incubation measurements weighted according to rate of passage. J. Agric. Sci., Camb. 92, 499503.

15. SAS. 2002. User's Guide: Statistical Analysis System. Version 9.1 Editions. SAS Inst., Inc., Cary, NC, USA.

16. Shannak, S., Südekum, K. -H. and Susenbeth, A. 2000. Estimating ruminal crude protein degradation with in situ and chemical fractionation procedures. Anim Feed Sci. Technol. 85:195-214.

17. Snedecor, G., Cochran, W. and Cox, D. 1989. Statistical Methods (8th edition). The Iowa State University Press.

18. Sniffen, C. J., O’Connor, J. D., Van Soest, P. J., Fox, D. G. and Russell, J. B. 1992. A net carbohydrate and protein system for evaluating cattle diets: II. Carbohydrate and protein availability. J. Anim. Sci. 70, 3562-3577.

19. Stern, M. D. and Satter, L. D. 1982. In vivo estimation of protein degradability in the rumen. In Protein Requirements for Cattle Symp. F. N. Owens, ed. Oklahoma State University, Stillwater. p57.

20. Tilly, J. M. and Terry, R. A. 1963. A two-stage technique for the in vitro digestion of forage crops. J. Br. Grassl. Soc.18:104-111.

21. Van Straalen, W. M. and Tamminga, S. 1990. Protein degradation of ruminant diets. In Feedstuff evaluation. 1. Livestock. Feedstuffs. Composition. J. Wiseman and D.J.A. Cole. (Eds.) Butterworths, London, UK, pp. 55-72.

22. Van Straalen, W. M., Odiga, J. J. and Mostert, W. 1997. Digestion of feed amino acids in the rumen and small intestine of dairy cows measured with nylon-bag techniques. Br. J. Nutr. 77:83-97.

23. Varvikko, T. and Lindberg, J. E. 1985. Estimation of microbial nitrogen in nylon-bag residues by feed ${ }^{15} \mathrm{~N}$ dilution. Br. J. Nutr. 54:473-481.

24. Zhao, G. Y. and Cao, J. E. 2004. Relationship between the in vitro-estimated utilizable crude protein and the Cornell Net Carbohydrate and Protein System crude protein fractions in feeds for ruminants. J. Anim. Physiol. Anim. Nutr. 88:301310.

(접수일자 : 2007. 2. 5. / 채택일자 : 2007. 6. 8.) 